\title{
SUSTAINABLE AGRICULTURE MANAGEMENTS TO CONTROL SOIL EROSION
}

\author{
MANEJO AGRICOLA SOSTENIBLE PARA CONTROLAR LA EROSION DEL SUELO \\ Artemi Cerdàa, ${ }^{\star}$, Enric Terol ${ }^{\mathrm{b}}$ \\ a Soil Erosion and Degradation Research Group, Department of Geography, University of Valencia, 46010 Valencia, Spain. \\ artemio.cerda@uv.es \\ ${ }^{\mathrm{b}}$ Department of Cartographic Engineering, Geodesy and Photogrammetry, Universitat Politècnica de València, Camino de Vera s/n, \\ 46022 Valencia, Spain. eterol@cgf.upv.es
}

\begin{abstract}
:
High rates of soil erosion compromise sustainable agriculture. In rainfed agricultural fields, erosion rates several orders of magnitude higher than the erosion rates considered tolerable have been quantified. In Mediterranean rainfed crops such as vineyards, almonds and olive groves, and in the new sloping citrus and persimmon plantations, the rates of soil loss make it necessary to apply measures to reduce them to avoid collapse in agricultural production. Managements such as weeds, catch crops and mulches (straw and pruning remains) are viable options to achieve sustainability. This work applies measurements through plots, simulated rainfall experiments and ISUM (Improved Stock-Unearhing method) to quantify the loss of soil at different temporal and spatial scales in fields of traditional management (herbicide or tillage) and under alternative management (mulches and plant covers). The work carried out at the experimental station for the study of soil erosion in the Sierra de Enguera and those of Montesa and Les Alcusses provide information on erosion plots under natural rain. Experiments carried out with simulated rain in fields of olive, almond, citrus, persimmon, vineyard and fruit trees report the hydrological and erosive response under low frequency and high intensity rains. And finally, the ISUM topographic method report the impact of long-term management, from the plantation. The results indicate that the loss of soil is greater $(x 10-1000)$ in soils under traditional management (tillage and herbicide) due to the fact that they remain bare for most of the year. The use of straw mulch immediately reduces soil erosion by two orders of magnitude. Also mulches from chipped pruned branches remains are very efficient but require more years to reduce soil loss. Weeds and catch crops are very efficient in controlling erosion.
\end{abstract}

Key words: soil erosion, ISUM, sustainable agriculture, mapping, runoff, Mediterranean

Resumen:

Las altas tasas de erosión del suelo comprometen una agricultura sostenible. En los campos agrícolas de secano se han cuantificado tasas de erosión varios ordenes de magnitud mayores a las tasas de erosión consideradas tolerables. En los cultivos de secano mediterráneo como el viñedo, almendro y olivar, y en las nuevas plantaciones de cítricos y caquis en pendiente, las tasas de pérdida de suelo hacen necesario la aplicación de medidas que las reduzcan para evitar el colapso en la producción agrícola. Manejos como las adventicias, abonos verdes y acolchados (paja y restos de poda) son opciones viables para alcanzar la sostenibilidad. Este trabajo aplica mediciones mediante parcelas, lluvia simulada e ISUM (Improved Stock-Unearhing method) para cuantificar a distintas escalas temporales y espaciales la pérdida de suelo en campos de manejo tradicional (herbicida o laboreo) y bajo manejos alternativos (acolchados y cubiertas vegetales). Los trabajos realizados en la estación experimental para el estudio de la erosión del suelo de la Sierra de Enguera y las de Montesa y Les Alcusses aportan información de parcelas de erosión bajo lluvia natural. Los experimentos realizados con lluvia simulada en campos de olivos, almendros, cítricos, caquis, viñedos y frutales informan de la respuesta hidrológica y erosiva bajo lluvias de baja frecuencia y alta intensidad. Y finalmente, el método topográfico ISUM nos indica el impacto del manejo a largo plazo, desde la plantación. Los resultados indican que la pérdida de suelo es mayor (x10-1000) en los suelos bajo manejos tradicionales (laboreo y herbicida) debido a que quedan desnudos gran parte del año. El uso de acolchados de paja reduce la erosión del suelo inmediatamente en dos ordenes de magnitud. También los acolchados de restos de poda son muy eficientes, pero requieren más años para conseguir reducir la pérdida de suelo. Las adventicias y los abonos verdes son muy eficientes en el control de la erosión.

Palabras clave: erosion del suelo, ISUM, agricultura sostenible, cartografía, escorrentía, Mediterráneo

\section{Introduction}

Soil erosion is not sustainable in agriculture landscapes and induces severe land degradation processes (Panagos and Katsoyiannis 2019). Along the 20th century, soil erosion was a key worldwide environmental problem that reduces the agriculture production, farmer's income and damage the soil sphere (Brown 1981; Oliver and Gregory 2015; Keesstra et al. 2016). Forest lands use to show low erosion rates. However, agriculture lands

*Corresponding Author: Artemi Cerdà, artemio.cerda@uv.es 
contribute with the highest soil losses measured in the Planet. This is due to the intense ploughing (Turtola et al. 2007), abuse of herbicides Cerdà et al. 2021), expansion of agriculture in rugged terrains (Shi et al. 2012), and the design of soil managements that threat the soil (RodrigoComino et al. 2018), such as soil compaction (Parker 1995) and soil degradation (Hill et al. 1995), which resulted in high erosion rates (see Figure 1 as an example).

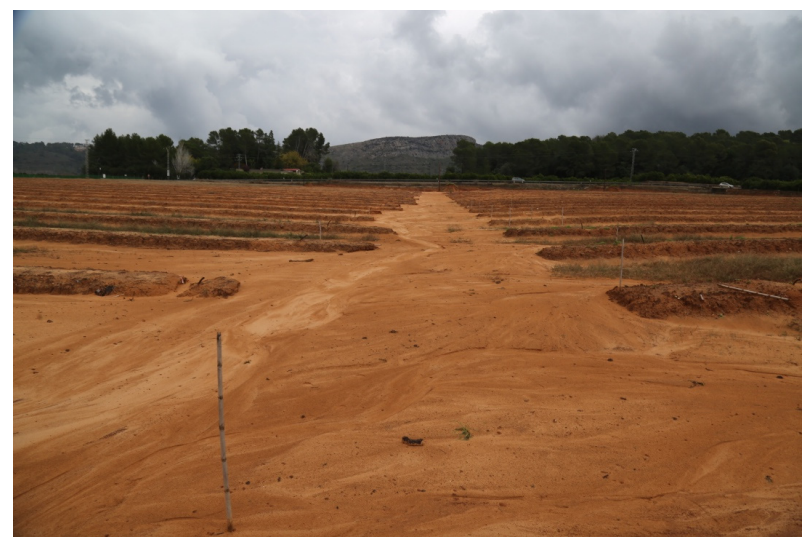

Figure 1: Soil erosion rates in Carcaixent (Spain) due to the plantation of new citrus crops. During the plantation works the soil is bare and soil erosion rates reach high rates. November 2019.

In the past, the strategies to control soil erosion were based on terracing and afforestation (Smith 1914). However, the restoration strategies based on plant cover and mulching were not widespread. The use of experimental research was initiated in the 1930s in the USA and resulted in a better understanding of the soil erosion and land degradation processes (Lutz 1935) and the initiation of the soil erosion control investigations (Ayres 1937) based on the understanding of soil erosion process and related mechanisms such as splash and raindrop impact (Ellison 1945). In the first half of the 20th century, soil erosion research was spread to different parts of the world with the origin in United States of America (Stamp 1938) and, then, plants were found to be a suitable option to control the soil losses in degraded lands (Fig. 2).

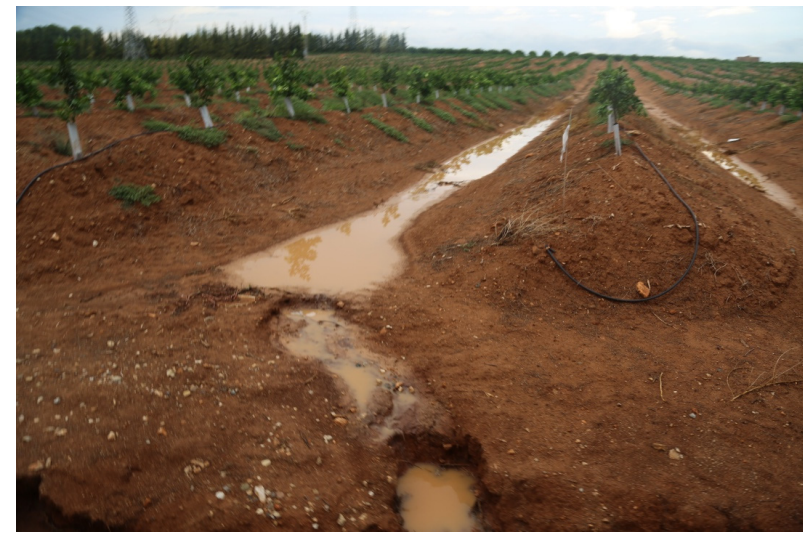

Figure 2: Runoff generation and soil erosion rates in Montesa (Spain) after one year of the plantation of citrus. Bare soils due to the abuse of herbicides results in high runoff and soil losses. October 2018.
High soil erosion rates were found under different crops. In cereals, soil erosion rates are very high due to the bare surfaces (De Santisteban et al. 2006; López-Vicente et al. 2020). Other crops also shown soil erosion rates due to the bare soils. For instance, olive groves are characterised by the higher soil losses such as was found by Nekhay et al. (2009) and Sastre et al. (2017). Vineyards shown high erosion rates too, mainly due to the intense ploughing and the lack of vegetation cover and the loss of the canopy during the winter (Rodrigo-Comino 2018). Orange production also contribute to high erosion rates characterised such as was found in China (Liu et al. 2012) and the Mediterranean belt (Cerdà et al. 2017). In the last three decades, a growth of the soil erosion measurements found that some other crops contribute to high erosion rates (Keesstra et al. 2018; Borrelli et al. 2020).

The mechanization of the agriculture production results in higher erosion rates in citrus, vineyards and olive plantations due to the soil degradation, increase in soil bulk density, the removal of the terraces and the loss of. Orchards and groves use to contribute with high erosion rates such as the research on apricots (Keesstra et al. 2016), almonds and persimmons (Rodrígo-Comino et al. 2018), or avocado (Fig. 3).

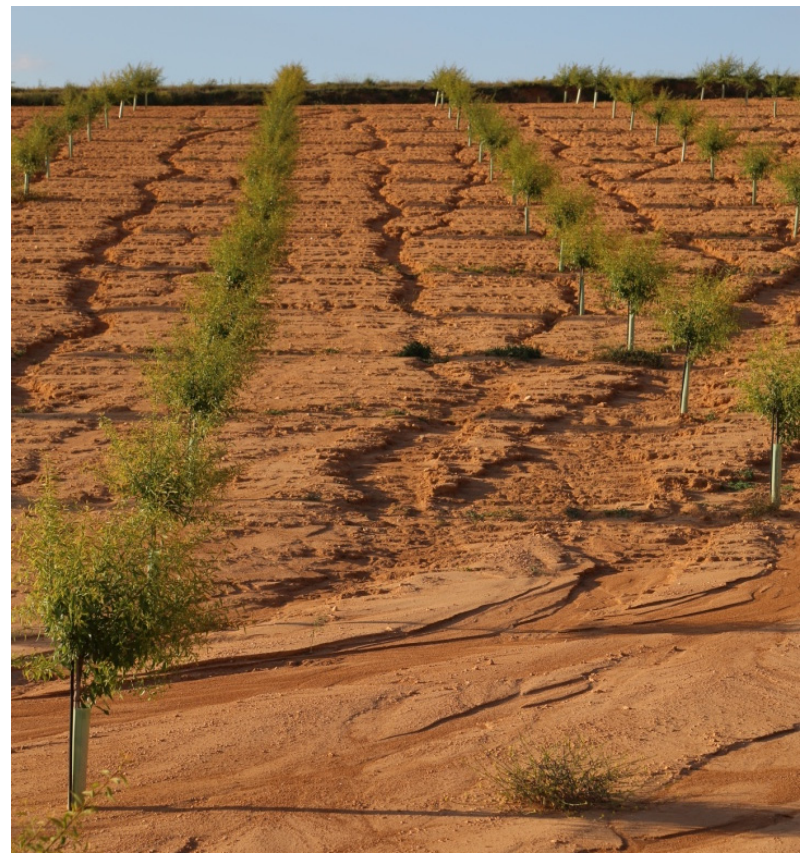

Figure 3: Soil erosion in almond plantations in Font de la Figuera results in gully and rill formation. June 2018.

The scientific research devoted to soil erosion found that the highest soil erosion rates were found during the plantation due to the soil compaction as a consequence of trampling and mechanization (Rodrígo-Comino et al. 2017 ) and the reduction in soil hydraulic conductivity and the reduction of the soil infiltration rates. This resulted in an increase in runoff generation and soil losses for some years due to the lack of vegetation cover (RodrigoComino et al. 2018). The impact of the plantation works and the development of new plantation was found also as the key factor by Rodrigo-Comino et al. (2017) due to the impact of the transport of equipment that results in compacted soils, the bare surfaces and the lack of crop cover due to the low biomass of the recently planted 
vineyards and the increase in runoff connectivity. The overview given here about the conditions of the agriculture land from the soil erosion point of view shows an environmental problem: an acceleration of the soil losses and then, the risk of the sustainability of the agriculture production.

\section{Material and Methods}

\subsection{Topographical measurements}

The topographical measurements were done applying the Improved Stock Unearthing method (ISUM) (RodrigoComino et al. 2018). This method is an update and improvement of the one developed by previous researchers in in vineyards (Brenot et al. 2008) and applied here to different crops with crafted trees: almond, citrus, persimmon, peaches and apricots such as Figure 4 shows.

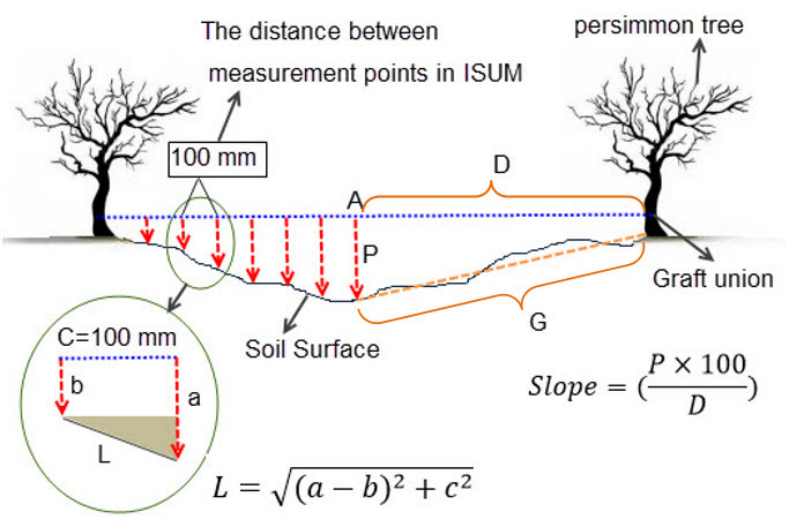

Figure 4: ISUM measurements and calculations.

The use of topographical measurements with ISUM is based in a survey of the topography of the plot done in the year of the measurement (2017-2021 upon the study sites) and the original topography during the plantation of the field. The original topography is calculated by means of the craft of the trees. For the ISUM (Improved Stock Unearthing Method) measurements at each study site were done at inter-row lines (Fig. 5).

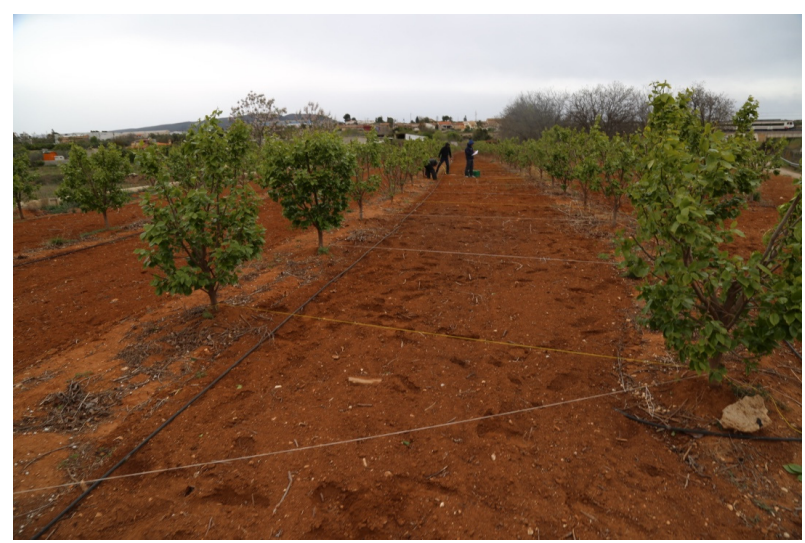

Figure 5: ISUM measurements in persimmon fields in Canals.

At each farm a plot of $5 \times 40$ meters was sampled. This is a total of 500 measurements of ISUM in each plot. A 1 $\mathrm{mm}$ thick nylon rope $(600 \mathrm{~mm}$ length) was roped from tree to tree (see Figs. 2 and 3 ) at the graft' height. The height of the rope to the soil surface was measured each $10 \mathrm{~cm}$ intervals along the rope. This way, 50 measurement points were collected in each sampling from tree (1 measurement) to tree (1 measurement) and between trees (48 measurements). A total of 2000 measurements (40 pair of trees $\times 50$ measurement points between trees) were measured. Following the methodology of RodrigoComino and Cerdà (2018) and their use in other publications in Persimmon, Saturn Peaches (Cerdà et al. 2020) and orange plantations (Rodrigo-Comino et al. 2017) the selected inter-line space was surveyed to determine the soil bulk density that will allow to transform the topographical changes in soil erosion and soil redistribution maps.

After personal communication with the farmers of the region, and confirmed by the farmer that planted the trees, the original height of the graft union was assumed uniform for all trees and specified at $7 \mathrm{~cm}$. Upon the measurements, a topographical map was created in ArcGIS 10.3 through interpolation of measured points in each plot. To calculate the soil erosion rates at the studied plot, the Surface Volume tool of ArcGIS 10.3 was used to determine the changes in the topography. This geoprocessing tool represents the volume of a surface above (original topography when the trees were planted 12 years ago) or below (topography during the sampling period) a given reference such previously applied (Cerdà et al. 2021). In this study, we applied the Eq. (1) calculate soil erosion and sediment accumulation rates $E V$ in $\mathrm{Mg}$ $\mathrm{ha}^{-1} \mathrm{yr}^{-1}$

$E V=\frac{V * B D_{S}}{A * T}$

where $V$ is the soil mobilized (volume) calculated from the topography in 2008 and $2020, B D_{S}$ is the soil bulk density measured with the core method, $A$ is the total area of the site and $T$ is the time since plantation (12 years) (Fig. 6). The core method consist in sampling the soil with a ring of $60 \mathrm{~mm}$ in diameter and $60 \mathrm{~mm}$ in depth.

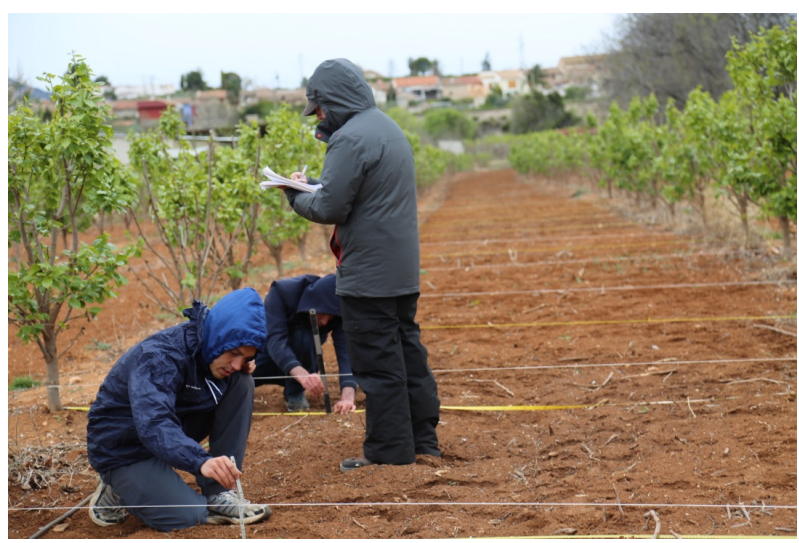

Figure 6: ISUM measurements in persimmon fields in L'Alcúdia de Crespins.

Descriptive statistics (median, standard deviation, mean, maximum, minimum) were applied to correlate between the derived bulk density and ISUM maps. We calculated them and the coefficient of variation. Spatial correlation analysis was conducted in ArcGIS 10.3 using the Band Collection Statistics. This tool estimates the correlation coefficient $\operatorname{Corr}_{i j}$ that explains the relationship between the two raster maps $\mathrm{i}$ and $\mathrm{j}$ using, Eq. (2). 


$$
\operatorname{Corr}_{i j}=\frac{\operatorname{Cov}_{i j}}{\delta_{i} \delta_{j}}
$$

where standard deviations of raster maps are defined by $\delta_{i}$ and $\delta_{j}$ and $\operatorname{Cov}_{i j}$ is the covariance matrix between raster maps ( $i$ and $j$ ) defined in Eq. (3).

$$
\operatorname{Cov}_{i j}=\sum_{K=1}^{N} \frac{\left(Z_{i k}-I_{-i}\right)-\left(Z_{j k}-I_{-j}\right)}{N-1}
$$

where $N$ is the total number of cells in each raster map, $Z_{k}$ is defined as a particular cell value of raster map $i$ or $j$, and $\mu$ is the mean value of each raster map. Correlation values changes between +1 to -1 , so that positive values denote a direct relationship between the two raster maps, negative values denote inverse correlation, and independence between them is denoted by zero.

To compare the means of measured soil variables including ISUM, Bulk density, Plant cover, and Organic matter in the four plots, the analysis of variance (ANOVA) was used in SPSS 17 software. Since the equal means assumption of the groups were not significant $(P<0.05$ was considered significant), so we used Games-Howell multiple comparison test to evaluate the significances of individual differences. Actually, Games-Howell test as a Post-Hoc test can help to detect which groups are different and what is direction of these different (Cerdà et al. 2021).

\subsection{Rainfall simulation experiments}

Plant, litter, rock fragment, and bare soil covers were measured before the rainfall simulation experiments and were determined by measuring 100 points regularly distributed at each $0.25 \mathrm{~m}^{2}$ plot, and then, considered as a percentage value. Soil sampling took place at each of the 80 research plots (10 in Control and 10 in Vicia sativa plot in February 2016, and August 2016, 2017 and 2018). The samples were taken a 0-6 cm depth with a ring of 6 $\mathrm{cm}$ of diameter and $6 \mathrm{~cm}$ depth. Grain size, soil moisture and organic matter and bulk density were determined from the samples collected in February 2016. Soil moisture and organic matter and bulk density were measured again at each rainfall simulation plot August in 2016, 2017 and 2018. The pipette method was used to determine the grain size. Bulk density was measured using the ring method. Soil organic matter was measured using the Walkley-Black method... Soil moisture was determined by the desiccation and measured in all the 80 samples. Twenty samples were collected at each sampling period (January 2016 and August 2016, 2017 and 2018), 10 for Vicia sativa management and 10 for Tillage (Fig. 7).

The experimental setup for the rainfall simulation experiments was identical than for the soil sampling. Ten plots per management (10 Tillage and 10 Vicia sativa) by four seasons (February 2016 and August 2016, 2017 and 2018) were used to carry out a total of 80 rainfall simulation experiments at $55 \mathrm{~mm} \mathrm{~h}^{-1}$ rainfall intensity for one hour on circular paired plots $\left(0.25 \mathrm{~m}^{2}\right)$. For the calibration, more information can be found in the comparisons articles performed under laboratory (Iserloh et al. 2013) and field conditions (Rodrigo-Comino et al. 2017). At each plot, runoff flow was collected at 1-min intervals and water volume was measured. The runoff coefficient was calculated as the percentage of rainfall water leaving the circular plot as overland flow. Runoff samples were desiccated $\left(105^{\circ} \mathrm{C}, 24 \mathrm{~h}\right)$ and sediment yield calculated on a weight basis to calculate soil loss per area and time $\left(\mathrm{Mg} \mathrm{ha}^{-1} \mathrm{~h}^{-1}\right)$. During the rainfall simulation experiments, time to ponding (time required for $40 \%$ of the surface to be ponded; $\mathrm{Tp}, \mathrm{s})$, time to runoff initiation ( $\mathrm{Tr}$, s) and time required by runoff to reach the outlet (Tro, s) were recorded. Tr-Tp and Tro-Tr were calculated, and they indicate how the ponding is transformed into runoff and how much time the runoff on the soil surface needs to reach the plot outlet. These parameters are good indicators of the hydrological connectivity within the plot.

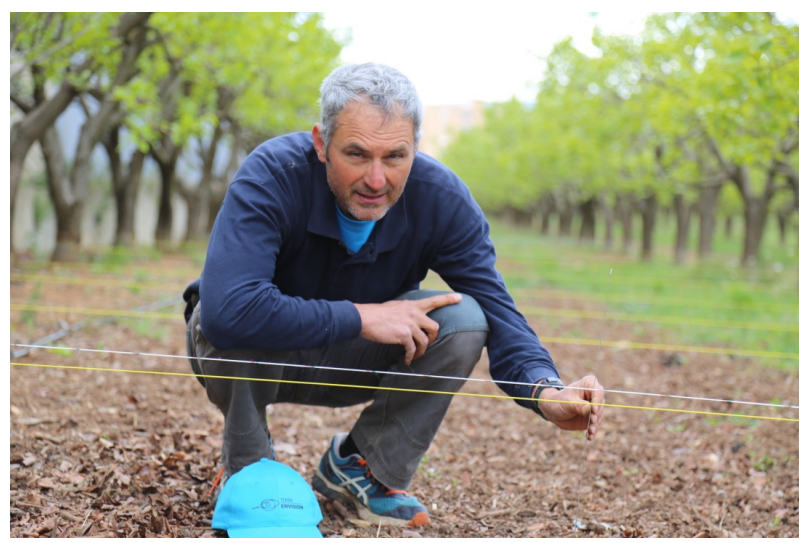

Figure 7: ISUM measurements in persimmon fields in Montesa.

The measured factors with a clear influence on soil erosion were depicted in box plots (Fig. 3) including the median (continuous line), averages (dotted lines) and outliers (black circles): vegetation and rock fragment covers, litter, bulk density, soil water content and organic matter. Then, these above-mentioned variables considered as key factors and the rainfall simulation results ( $\mathrm{Tp}, \mathrm{Tr}$, Tro, soil loss, etc.) were presented in form of tables with averages, standard deviation ( \pm ), maximum and minimum values. Furthermore, we compared the results per year and treatment using the t-test method. Since all the results showed a non-normal distribution (normality test Shapiro-Wilk), a Tukey test was performed. We considered that significant differences can be relevant at $\mathrm{P}<0.001$ levels. Finally, one linear graph (hydrological response per plot and year) and another scatter plot (soil loss vs runoff coefficient) were also depicted (Figs. 8 and 9).

\subsection{Soil erosion plot measurements}

A total of 4 pairs of sediment collectors installed on $2 \mathrm{~m}^{2}$ ( $1 \mathrm{~m}$ width $\times 2 \mathrm{~m}$ length) soil erosion plots were used to monitor runoff and soil loss in the tilled vineyard. Each plot boundary was demarcated by galvanized iron sheets (1 $\mathrm{mm}$ thick $\times 50 \mathrm{~mm}$ in height) and a $50 \mathrm{~L}$ container was installed at the outlet to collect the runoff and soil losses. The plots were laid in the inter-row areas close to the vine rows to avoid problems with the tractor passes. The collected sediment-laden runoff samples in the containers were transported to the laboratory after each rainfall event, weighed and air-dried to separate and quantify runoff and soil loss. The average values of runoff $\left(\mathrm{I} \mathrm{m}^{-2}\right)$ and soil loss $\left(\mathrm{g} \mathrm{m}^{-2}\right)$ of the 8 collectors represented the event (Fig. 10). 


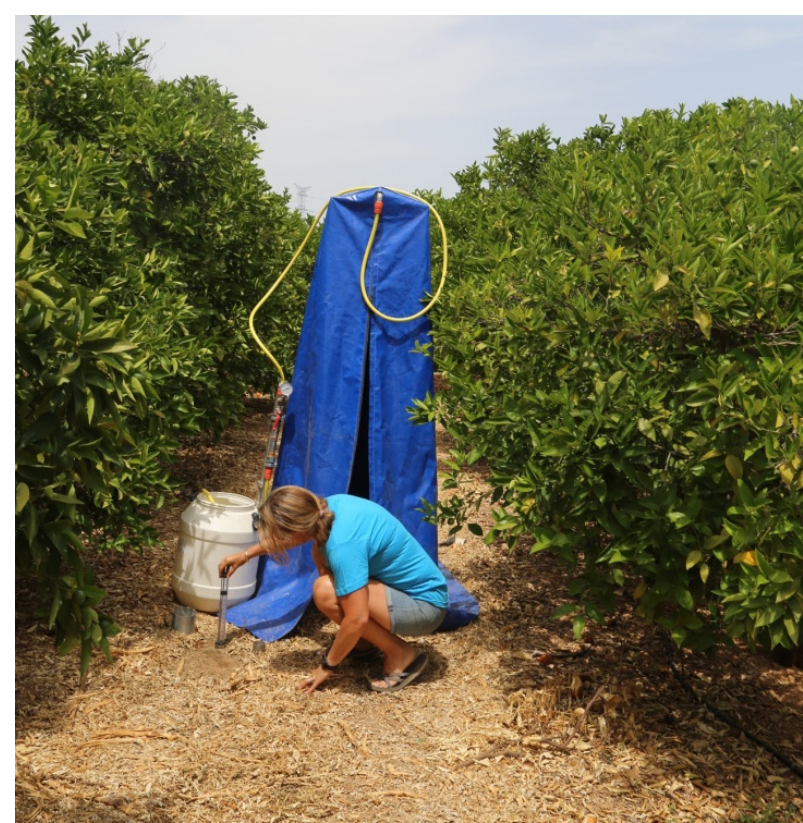

Figure 8: ISUM measurements in persimmon fields in Montesa.

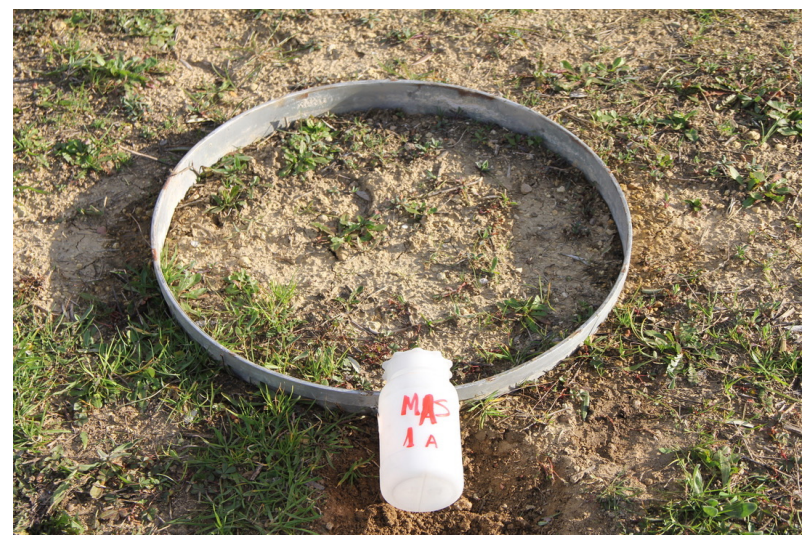

Figure 9: Example of rainfall simulation plot $\left(0.25 \mathrm{~m}^{2}\right)$.

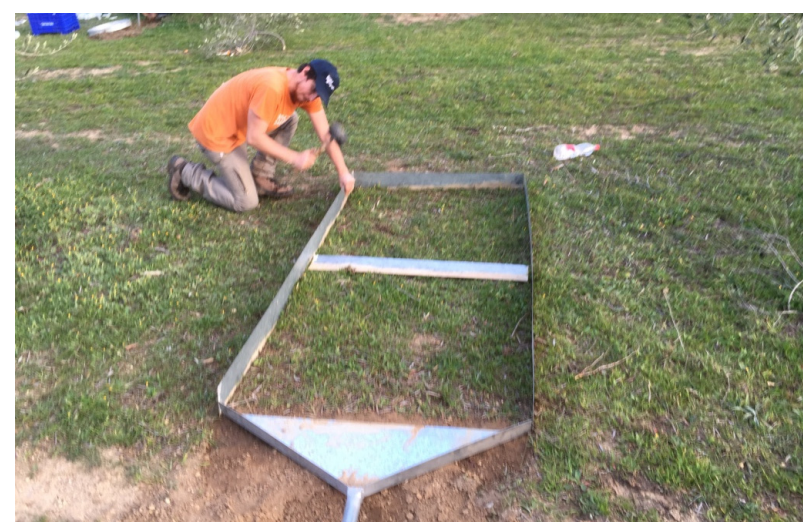

Figure 10: Soil erosion plot $\left(2 \mathrm{~m}^{2}\right)$ at the Sierra de Enguera experimental station.

A set of eight plots (4 plus 4 as paired plots) were established in 2002 and the first measurements took place in January 2004. Plots were constructed with aluminium sheets that acted as borders. The sheets were $1 \mathrm{~mm}$ thick $\times 50 \mathrm{~mm}$ in height $\times 1000$ (or 2000) mm long to achieve plots of different sizes. Each plot consisted of four subplots that were $1 \times 1 ; 1 \times 2 ; 1 \times 4$ and $2 \times 8$ m (width $x$ length) (Fig. 1). The tillage plot was tilled 4 times per year (April, May, June and August) to remove vegetation following traditional soil management for almond, fruit, olive and vineyard crops in the region. The tillage (control) plot was bare the entire year with the purpose of simulating fallow land, which was promoted by the European Union Common Agriculture Policies in similar areas where cereal production has low yields.

The abandonment of four plots took place in 2006 while the other four plots were maintained under tillage during the 11 experimental years. In 2004 and 2005 both plots were managed with tillage to determine their hydrological and erosional response before abandonment. Monitoring of the plots lasted until 2014, nine years after abandonment and eleven years after initiation of the experiment. Runoff ( $L$ ) and sediment yield $(\mathrm{kg})$ were measured after each rainfall event. Measurements of the vegetation and rock fragment cover were performed seasonally (January and July) and soil samples were collected with a $100 \mathrm{~cm}^{3}$ steel ring. The soil surface roughness was determined in the centre of the plots with the chain method. More than 6 hours without rainfall was use as the threshold to distinguish rainfall events. Runoff was collected from the plots using a collector (gutter) that was $0.15 \times 1 \mathrm{~m} \mathrm{(2m}$ in the $16 \mathrm{~m}^{2}$ plots, $\left.2 \times 8 \mathrm{~m}^{2}\right)$ and 0.15 $\mathrm{m}$ depth. The collected runoff was drained into containers of 125 and $250 \mathrm{~L}$ that were connected to the collector by a $0.4 \mathrm{~m}$-diameter pipe to store the runoff (deposits). Total storage capacities were $125,250,375$ and $600 \mathrm{~L}$ for the $1,2,4$, and $16 \mathrm{~m}^{2}$ plots, respectively. After each rainfall event, the runoff was measured and three samples per deposit were collected to determine the sediment concentration. Soil erosion rates $\left(\mathrm{Mg} \mathrm{ha}^{-1} \mathrm{yr}^{-1}\right)$ and runoff coefficients (\%) were also calculated for each rainfall event. The rainfall was measured with a raingauge and compared with the nearby Las Arenas meteorological station (AEMET) located $5 \mathrm{~km}$ from the study site. Soil and vegetation descriptions and sampling were made in December 2003 before the measurements were initiated and maintained during the experimental period.

\section{Results}

\subsection{ISUM}

We present here two examples of the use of ISUM to determine the soil erosion rates. The first one demonstre the impact of chemical and organic farming on soil erosion. The comparison of a 25-years old persimmon orchards in La Costera district shown high erosion rates on the chemical farming and very low or neglibible in the one under organic farming (Fig. 9). An increase in soil organic matter and a decrease in soil bulk density was also measured. The distribution of the soil lowering inform that the inter-row area is the most affected as a consequence of the passes of machinery and human trampling, The changes in soil bulk density confirms this issue (Fig. 11).

ISUM contributed with information coming from other regions of the Mediterranean. In the alluvial soil of the Ribera del Xúquer, we selected two farms under chemical farming and flood irrigation. The use of ISUM was very helpful to determine the final soil erosion rate and the soil redistribution along the 25 years of study. We confirmed that the soil erosion rates are non-sustainable (Fig. 12) and that the redistribution of the soil was due to the flow 
of irrigation, which resulted in higher erosion rates in the upper field area and accumulation in the lower part. Moreover, the area under the tree cover reached lower soil lowering, meanwhile the centre of the row reached the highest soil lowering. This is due to the impact of the tractor passes and the higher compaction of the soil (Fig. 12).

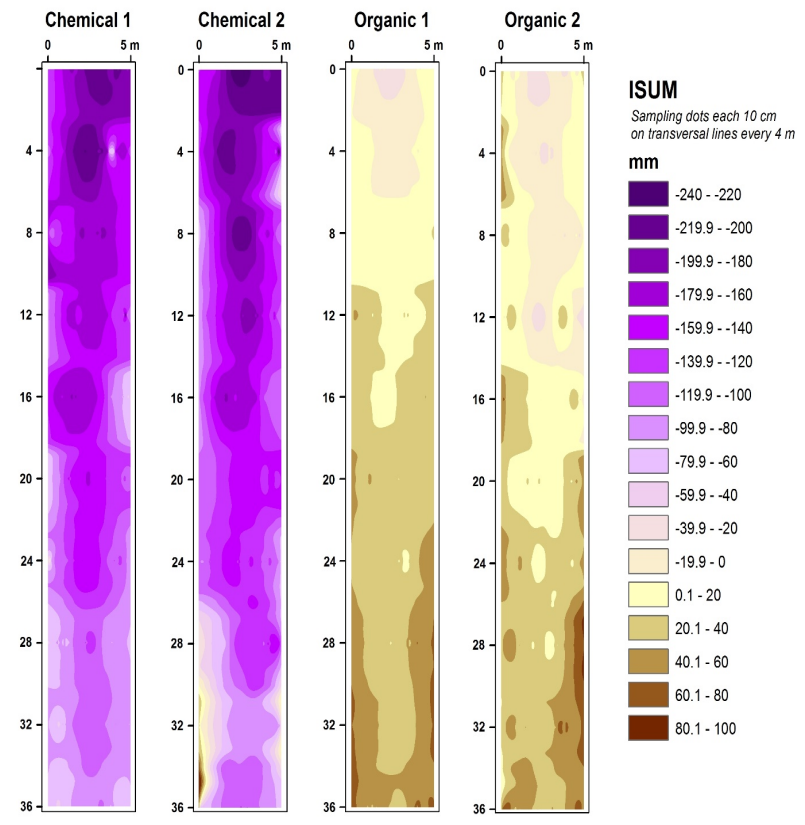

Figure 11: Soil lowering $(\mathrm{mm})$ in persimmon under organic and chemical farming.

The findings with ISUM on organic and chemically managed persimmon plantations demonstrate that the farmer's management is relevant to achieve the sustainable development in agriculture land. The lack of vegetation is the factor that induces the increase in soil erosion. It is also relevant the soil organic matter reduction due to the tillage or herbicide use. The compaction of the soil as a consequence of the trampling and the pass of machinery is also a key issue that need to be researched to achieve a sustainable agriculture management. In the last century, a continuous increase in the mechanisation of the agriculture sector resulted in heavy machinery that does not contribute to a healthier soil management. However, the reduction of mechanisation will reduce farmer's income, and this will threat the sustainability of the production. The reduction of the soil losses and then the use of a regenerative agriculture will be based on the increase of plant cover. The use of ISUM assess the long-term soil erosion rates in agriculture land, and we found that they are not sustainable. The next step in this research will be to measure the soil erosion rates under different management with measurements under simulated rainfall. The challenge is to find the right plant cover (or mulches) that will control the high erosion rates. This challenge should also accomplish the challenge of the sustainability from the point of view of the economy. A proper income for the farmers is definitive to maintain an active agriculture.

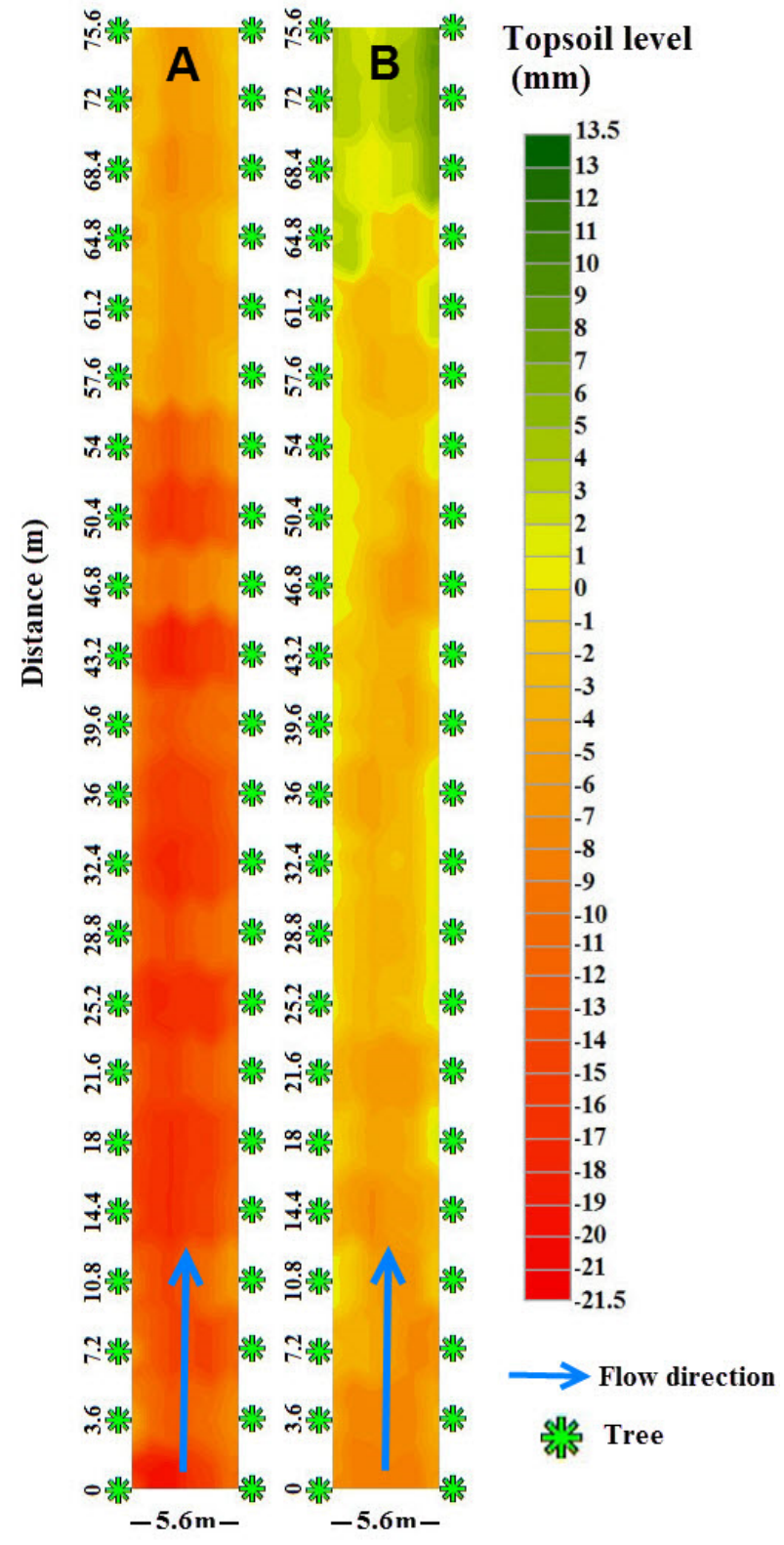

Figure 12: Soil lowering $(\mathrm{mm})$ in Saturn Peaches plantations in L'Alcúdia site $(A)$ and Benimodo site (B).

\subsection{Rainfall simulation experiments to achieve a sustainable soil erosion rate}

Rainfall simulation experiments were carried out in the vineyards of Els Alforins, valley of Les Alcusses, under rainfall simulation experiments at $55 \mathrm{~mm} \mathrm{~h}^{-1}$ during one hour and on a $0,25 \mathrm{~m}^{2}$ to determine the impact of agriculture management and the time since changes in management. One of the plots was under tillage, which is the Millenia old system to manage the agriculture soil in vineyards. The paired plot was sown with a catch crop (Vicia sp.) and the reduction of the soil erosion was recorded already in the first set of experiments in 2016. The measurements carried along 3 years confirm the high erosion rates found under the tillage conditions and the control that exert the use of catch crops. In agriculture land under vineyards we propose the use of catch crops to reduce the soil losses but also to increase the amount of nitrogen and organic matter in the soil. Vicia sp. was 
found to be a very positive catch crop for vineyards (Fig. 13).

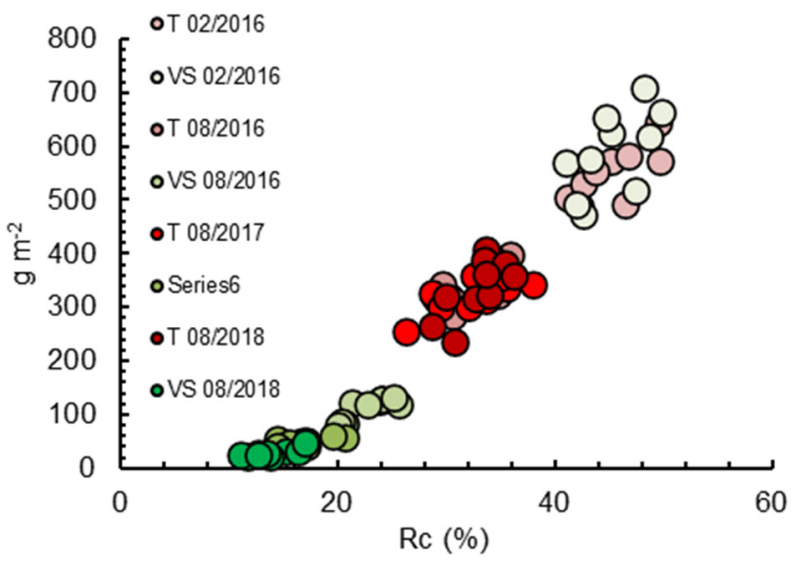

Figure 13: Soil erosion rates measured by means of simulated rainfall ( $55 \mathrm{~mm} \mathrm{~h}^{-1}, 0,25 \mathrm{~m}^{2}$ plot) in vineyards under Tillage and Catch crops cover.

The use of rainfall simulation experiments assesses the impact of different agriculture management under low frequency high magnitude rainfall events, which are the ones that results in high erosion rates. This is very relevant in Mediterranean Ecosystems where high magnitude rainfall events are rare but drive the geomorphological processes and threat the sustainability of agriculture land (Fig. 14).

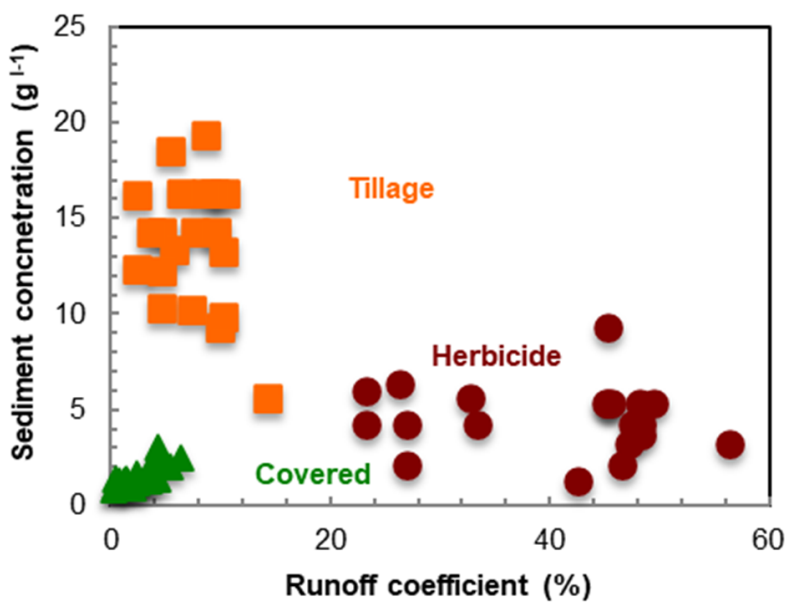

Figure 14: Sediment concentration measured by means of simulated rainfall $\left(55 \mathrm{~mm} \mathrm{~h}^{-1}, 0,25 \mathrm{~m}^{2}\right.$ plot) in vineyards under Tillage, herbicide and cover crops cover in Apricot plantations in Aielo de Malferit, Eastern Iberian Peninsula.

Apricot production in Eastern Iberian Peninsula is based in intense tillage or herbicide treatments and this resulted in high erosion rates, Herbicides induce an increase in runoff yield, meanwhile tillage, enhance the increase in sediment concentration (Fig. 12). The use of cover crops under rainfall simulation experiments confirmed that the large sediment and water delivery in apricots farms can be controlled. A cover of weeds reduces the sediment delivery in two orders of magnitude and in $40 \%$ the runoff yields. There is a clear solution to the soil erosion in fruit production and is based on a healthy vegetation cover in the inter-row.

\subsection{Soil erosion measurement on plots and under natural rainfall}

To properly assess soil erosion, it is necessary to use natural rainfall to determine the variability of the sediment and water delivery along the time and space. With this purpose a soil erosion experimental station was built at the Sierra de Enguera (Fig. 13) to measure along 14 years the soil losses. The measurements carried out demonstrate that the high soil erosion rates measured on herbicide treated fields can be reduced with the use of straw mulches. The use a cover of straw reduces the raindrop impact and increase the infiltration, which result in less sediment and water delivered to the fluvial system and other agriculture fields. The use of plots of different sizes contributes to better understand the connectivity of the flows and the delivery of material within the field and from the field to the rivers. A reduction in the soil and water delivery was found with the increase in the size and length of the plots, which shed light into the importance of the length of the fields to reduce the soil erosion rates (Fig. 15). The measurements carried out at the Soil Erosion Experimental Station of Sierra de Enguera demonstrates that a proper management of the agriculture fields are definitive to achieve a sustainable use of the land. A reduction in the soil erosion rates is necessary to achieve the wishes sustainability (Figs. 16 and 17).

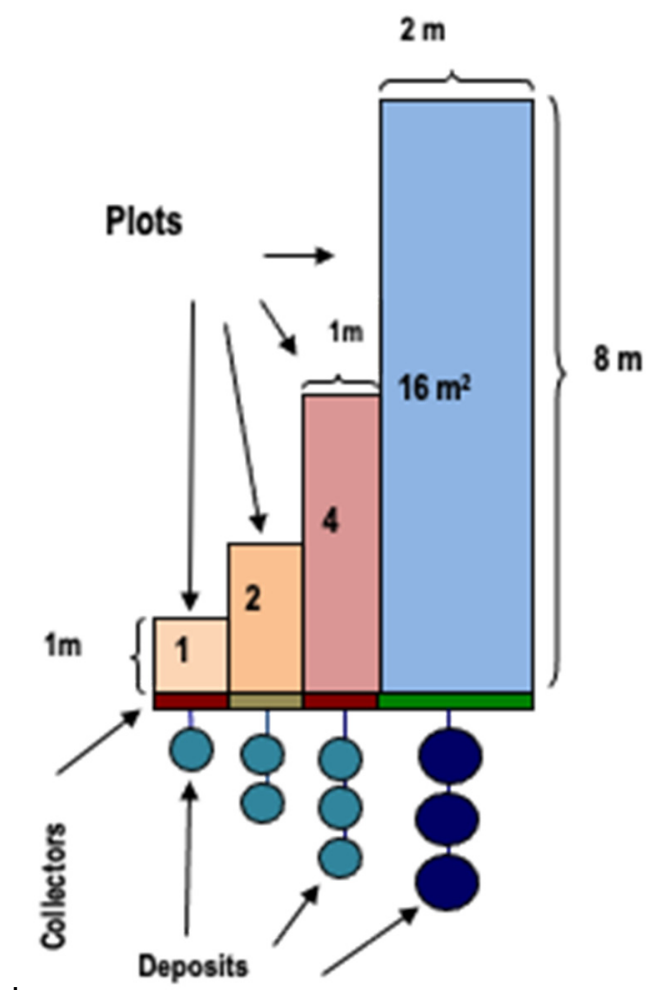

Figure 15: Sketch of the soil erosion plots at the Sierra de Enguera Soil Erosion Experimental Station.

Soil losses along 11 years at the Sierra de Enguera Soil Erosion Experimental Station was $2.19 \mathrm{Mg} \mathrm{ha}^{-1} \mathrm{y}^{-1}$ for the straw covered plot and $12.03 \mathrm{Mg} \mathrm{ha}^{-1} \mathrm{y}^{-1}$ for the herbicide treated plots. The yearly variability was high as the straw covered plots moved from $15.01 \mathrm{Mg} \mathrm{ha}^{-1} \mathrm{y}^{-1}$ the year previously to the straw application and $0.03 \mathrm{Mg} \mathrm{ha}^{-1} \mathrm{y}^{-1}$ ten years later. The Bare plot ranged from $1.26 \mathrm{Mg} \mathrm{ha}^{-1} \mathrm{y}$ 1 till $29.22 \mathrm{Mg} \mathrm{ha}^{-1} \mathrm{y}^{-1}$. There is trend of reduction in soil 
erosion rates in the straw covered plot from 2004 and 2014 (Table 1). The herbicide covered plot shown a bare surface along the 11 years of study meanwhile the straw covered plot reduced the soil losses immediately. Our conclusions are that the straw covered plot reduce the soil losses in one order of magnitude and contribute to achieve a sustainable agriculture land management. The straw was added yearly, and a recovery of plants was measured with an increase of herbs by local plants and also the germination of the barley seeds that arrived with the straw bales (Table 1).

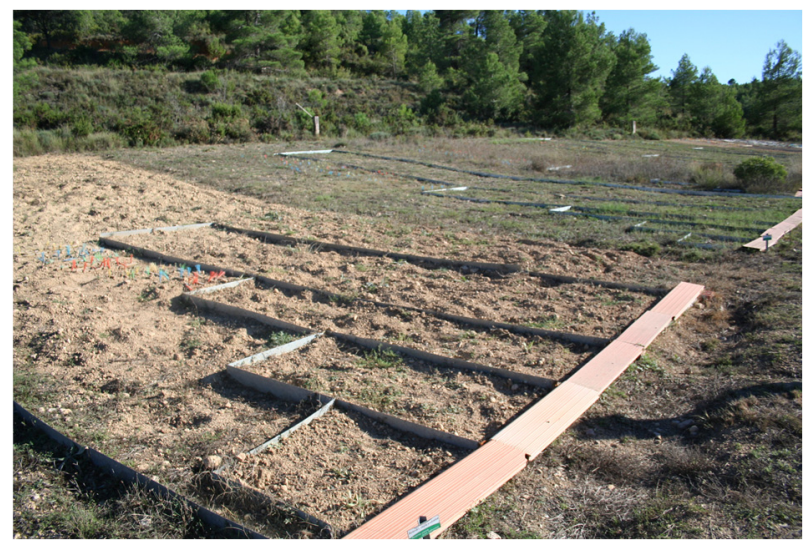

Figure 16: View of the soil erosion plots at the Sierra de Enguera Soil Erosion Experimental Station.

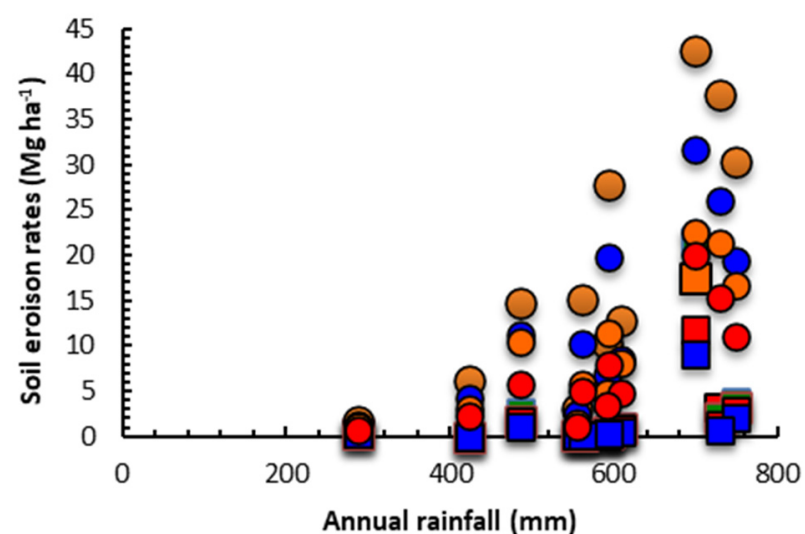

Figure 17: Soil erosion rates per annual rainfall in Bare (circles) and Straw (squares).

\section{Conclusions and further research}

The experimental research carried out with ISUM, soil erosion plots and rainfall simulators demonstrate that there are high erosion rates in agriculture land but there are solutions. The high erosion rates result in a nonsustainable agriculture and they must be reduced to achieve a stable production of food. The control of the soil erosion rates can be achieved with a cover of mulch (straw) or the use of cover and catch crops. Our experiments demonstrate that straw mulch achieve an immediate control of the soil losses, meanwhile the use of weeds and catch crops will delay the reduction in soil and water losses at least a year. After a decade, our measurements under natural rainfall and plots demonstrate that the soil losses reduction can reach more than one order of magnitude.
Table 1: Soil erosion rates from 2004 till 2014 at the Sierra de Enguera Soil Erosion Experimental Station.

\begin{tabular}{c|c|c|c} 
Year & Rainfall $(\mathrm{mm})$ & Straw $\left(\mathrm{Mg} \mathrm{ha}{ }^{-1}\right)$ & Bare $\left(\mathrm{Mg} \mathrm{ha}^{-1}\right)$ \\
\hline 2004 & 700 & 15.01 & 29.22 \\
2005 & 288 & 0.37 & 1.26 \\
2006 & 485 & 1.77 & 10.58 \\
2007 & 749 & 3.03 & 19.39 \\
2008 & 609 & 0.83 & 8.57 \\
2009 & 729 & 1.84 & 25.17 \\
2010 & 554 & 0.15 & 2.07 \\
2011 & 590 & 0.37 & 6.33 \\
2012 & 594 & 0.50 & 16.76 \\
2013 & 560 & 0.13 & 9.06 \\
2014 & 422 & 0.03 & 3.90 \\
Average & 571 & 2.19 & 12.03
\end{tabular}

The long-term measurements applied with ISUM indicate that values one or two orders of magnitude higher than the tolerable soil erosion rates are found in the Mediterranean crops, and that they must be reduced. The research carried out with soil erosion plots highlight that there are few but intense rainfall events that are the key to understand the soil erosion rates, both, spatial distribution and temporal changes. Those rainfall events use to trigger the highest soil erosion rates, and in a period of 10 years can results in $70 \%$ of the total soil losses. This is why, the research with simulated rainfall was based on rainfall events with rainfall intensities of 55 $\mathrm{mmh}^{-1}$. This low frequency - high magnitude rainfall events are the ones that determine the fate of the agriculture land sustainability. Our investigations demonstrate that under those extreme thunderstorms, the use of mulches, weeds and cover crops is also efficient to reduce the soil losses.

Future research on the issue of soil erosion should also investigate the economic impact of soil erosion, and the benefit to control the soil losses. Moreover, the perception of the farmers, and other stakeholders should be researched as the opinion of the citizens will contribute (or not) to change the way we manage the agriculture land.

\section{Acknowledgements}

This research was funded by the European Union Seventh Framework Programme (FP7/2007-2013) under grant agreement $\mathrm{n}^{\circ} 603498$ (RECARE project). Artemi Cerdà thanks the Co-operative Research programme from the OECD (Biological Resource Management for Sustainable Agricultural Systems) for its support with the 2016 CRP fellowship (OCDE TAD/CRP JA00088807). We thank Nathalie Elisseou Léglise for her kind management of our financial support. The collaboration of students from the Degree of Geography and Environmental Sciences was fruitful and enjoyable. The music of Hilari Alonso (A prop) was an inspiration during the writing of this paper at the COVID19 time. 


\section{References}

AYRES, Q.C., 1937. Soil erosion and its control. Soil Science, 43(5), pp. 391.

BORRElLI, P., ROBINSON, D. A., PANAGOS, P., LUGATO, E., YANG, J. E., ALEWELL, C., and BALLABIO, C., 2020. Land use and climate change impacts on global soil erosion by water (2015-2070). Proceedings of the National Academy of Sciences, 117(36), pp. 21994-22001.

BRENOT, J., QUIQUEREZ, A., PETIT, C., and GARCIA, J. P., 2008. Erosion rates and sediment budgets in vineyards at 1-m resolution based on stock unearthing (Burgundy, France). Geomorphology, 100(3-4), pp. 345-355.

BROWN, L.R., 1981. World population growth, soil erosion, and food security. Science, 214, pp. 995-1002. DOI: 10.1126/science.7302578

CERDÀ, A., RODRIGO-COMINO, J., GIMÉNEZ-MORERA, A., and KEESSTRA, S. D., 2017. An economic, perception and biophysical approach to the use of oat straw as mulch in Mediterranean rainfed agriculture land. Ecological Engineering, 108, pp. 162-171.

CERDÀ, A., RODRIGO-COMINO, J., YAKUPOĞLU, T., DINDAROĞLU, T., TEROL, E., MORA-NAVARRO, G., and VAVERKOVÁ, M. D., 2020. Tillage Versus No-Tillage. Soil Properties and Hydrology in an Organic Persimmon Farm in Eastern Iberian Peninsula. Water, 12(6), pp. 1539.

CERDÀ, A., TEROL, E., and DALIAKOPOULOS, I. N., 2021. Weed cover controls soil and water losses in rainfed olive groves in Sierra de Enguera, eastern Iberian Peninsula. Journal of Environmental Management, 290, pp. 112516.

DE SANTISTEBAN, L. M., CASALÍ, J., and LÓPEZ, J. J., 2006. Assessing soil erosion rates in cultivated areas of Navarre (Spain). Earth Surface processes and landforms: The Journal of the British Geomorphological Research Group, 31(4), pp. 487-506.

ELLISON, W.D., 1945. Some effects of raindrops and surface-flow on soil erosion and infiltration. Eos, Transactions American Geophysical Union, 26, pp. 415-429. DOI: 10.1029/TR026i003p00415

HILL, J., MEGIER, J., and MEHL, W., 1995. Land degradation, soil erosion and desertification monitoring in Mediterranean ecosystems. Remote Sensing Reviews, 12(1-2), pp. 107-130.

ISERLOH, T., RIES, J. B., ARNÁEZ, J., BOIX-FAYOS, C., BUTZEN, V., CERDÀ, A., and WIRTZ, S., 2013. European small portable rainfall simulators: A comparison of rainfall characteristics. Catena, 110, pp. 100-112.

KEESSTRA, S., PEREIRA, P., NOVARA, A., BREVIK, E. C., AZORIN-MOLINA, C., PARRAS-ALCÁNTARA, L., and CERDÀ, A., 2016. Effects of soil management techniques on soil water erosion in apricot orchards. Science of the Total Environment, 551, pp. 357-366.

KEESSTRA, S., MOL, G., DE LEEUW, J., OKX, J., DE CLEEN, M., and VISSER, S., 2018. Soil-related sustainable development goals: Four concepts to make land degradation neutrality and restoration work. Land, 7(4), pp. 133.

LIU, Y., TAO, Y., WAN, K. Y., ZHANG, G. S., LIU, D. B., and XIONG, G. Y., 2012. Runoff and nutrient losses in citrus orchards on sloping land subjected to different surface mulching practices in the Danjiangkou Reservoir area of China. Agricultural Water Management, 110, pp. 34-40.

LÓPEZ-VICENTE, M., CALVO-SEAS, E., ÁLVAREZ, S., and CERDÀ, A., 2020. Effectiveness of Cover Crops to Reduce Loss of Soil Organic Matter in a Rainfed Vineyard. Land, 9, pp. 230.

LUTZ, J.F., 1935. The Relation of Soil Erosion to Certain Inherent Soil Properties. Soil Science, 40, pp. 439-458.

NEKHAY, O., ARRIAZA, M., and BOERBOOM, L., 2009. Evaluation of soil erosion risk using Analytic Network Process and GIS: A case study from Spanish mountain olive plantations. Journal of Environmental Management, 90, pp. 30913104. DOI: 10.1016/j.jenvman.2009.04.022

OLIVER, M.A., and GREGORY, P.J., 2015. Soil, food security and human health: a review. European Journal of Soil Science, 66, pp. 257-276. DOI: 10.1111/ejss.12216

PANAGOS, P., and KATSOYIANNIS, A., 2019. Soil erosion modelling: The new challenges as the result of policy developments in Europe. Environmental Research, 172, pp. 470-474. DOI: 10.1016/j.envres.2019.02.043

PARKER, K.C., 1995. Effects of complex geomorphic history on soil and vegetation patterns on arid alluvial fans. Journal of Arid Environments, 30, pp. 19-39. DOI: 10.1016/S0140-1963(95)80036-0

RODRIGO-COMINO, J., 2018. Five decades of soil erosion research in "terroir". The State-of-the-Art'. Earth-Science Reviews, 179, pp. 436-447. DOI: 10.1016/j.earscirev.2018.02.014.

RODRIGO-COMINO, J., and CERDÀ, A., 2018. Improving stock unearthing method to measure soil erosion rates in vineyards. Ecological Indicators, 85(Supplement C), pp. 509-517. DOI: 10.1016/j.ecolind.2017.10.042.

RODRIGO-COMINO, J., BREVIK, E., and CERDÀ, A., 2017. The age of vines as a controlling factor of soil erosion processes in Mediterranean vineyards. Science of The Total Environment. DOI: 10.1016/j.scitotenv.2017.10.204 
RODRIGO-COMINO, J., KEESSTRA, S. D., and CERDÀ, A., 2018. 'Connectivity assessment in Mediterranean vineyards using improved stock unearthing method, LiDAR and soil erosion field surveys. Earth Surface Processes and Landforms, 43(10), pp. 2193-2206. DOI: 10.1002/esp.4385.

SASTRE, B., BARBERO-SIERRA, C., BIENES, R., MARQUES, M. J., and GARCÍA-DÍAZ, A., 2017. Soil loss in an olive grove in Central Spain under cover crops and tillage treatments, and farmer perceptions. Journal of Soils and Sediments, 17(3), pp. 873-888.

SHI, Z.H., FANG, N.F., and WU, F.Z., 2012. Soil erosion processes and sediment sorting associated with transport mechanisms on steep slopes. Journal of Hydrology, 454-455, pp. 123-130. DOI: 10.1016/j.jhydrol.2012.06.004

SMITH, J. R., 1914. Soil erosion and its remedy by terracing and tree planting. Science, 39(1015), pp. 858-862.

STAMP, L.D., 1938. Land Utilization and Soil Erosion in Nigeria. Geographical Review, 28, pp. 32-45. DOI: $10.2307 / 210564$

TURTOLA, E., ALAKUKKU, L., and UUSITALO, R., 2007. Surface runoff, subsurface drainflow and soil erosion as affected by tillage in a clayey Finnish soil. Agricultural and Food Science, 16, pp. 332-351. DOI: 10.2137/145960607784125429 